\title{
OS JOVENS E A ESCRITA: PRÁTICAS ESCOLARES E EXTRAESCOLARES EM PORTUGAL ${ }^{1}$
}

\author{
INÊS CARDOSO ${ }^{*}$ \\ ORCID: https://orcid.org/0000-0003-2687-2424 \\ LUÍSA ÁLVARES PEREIRA ${ }^{2 * *}$ \\ ORCID: https://orcid.org/0000-0002-9742-2351 \\ CÉLIA DA GRAC̣A LOPES ${ }^{3}$ *** \\ ORCID: https://orcid.org/0000-0002-3556-4266 \\ RUI PATRÍCIO ANDRADE PEREIRA LOPES ${ }^{2 * * *}$ \\ ORCID: https://orcid.org/0000-0002-2026-7920
}

RESUMO: Apresentaremos as práticas de escrita, em contextos escolares (por injunção professoral) e extraescolares (livres), reportadas por alunos, dos 9 aos 15 anos, no Ensino Básico (EB) em Portugal, por meio de inquérito por questionário a nível nacional. Essas práticas são expressão da vasta e dinâmica relação com a escrita (re)construída pelos sujeitos. A Didática da Escrita (DE) tem salientado, justamente, a relevância de conhecer mais aprofundadamente a relação que os indivíduos (re)constroem com o ato de escrever, pois nela estão ancoradas as motivações e os fatores de afastamento e rejeição desta prática de produção verbal. Os resultados indicam maior diversidade de escritos no contexto extraescolar, contrastando com focos de atuação escritural mais preponderantes na escola, procurando atender a prioridades de ensino-aprendizagem. Emergem, contudo, elementos de conexão entre os dois contextos, que (in)formam para uma atuação didática mais favorecedora de um percurso escritural significativo para os sujeitos.

Palavras-chave: Relação com a escrita; Escrita escolar; Escrita extraescolar; Ensino da escrita; Didática da Escrita.

\footnotetext{
${ }^{1}$ York University, Ontario, Toronto, Canadá.

${ }^{2}$ Universidade de Aveiro, Portugal.

${ }^{3}$ Agrupamento de Escolas João da Silva Correia, Portugal.

"Doutorada em Didática, Sessional Assistant Professor, Docente do Camões, Instituto da Cooperação e da Língua; integra o Centro de Investigação "Didática e Tecnologia na Formação de Formadores" (CIDTFF); membro do grupo ProTextos: Ensino e Aprendizagem da Escrita de Textos. E-mail:<icardoso@yorku.ca>

" Professora Auxiliar com Agregação no Departamento de Educação e Psicologia (DEP) da Universidade de Aveiro (UA); CIDTFF; coordenadora do grupo ProTextos. E-mail:<lpereira@ua.pt > .

*** Professora do 1. ${ }^{\circ}$ Ciclo do Ensino Básico; Doutoranda em Multimédia em Educação - UA, onde também é colaboradora do grupo ProTextos. E-mail:<celia.graca@gmail.com>.

****Doutorando em Multimédia em Educação - DEP, UA. E-mail:< patricio72@hotmail.com>
} 
YOUTH AND WRITING: IN-SCHOOL AND OUT OF SCHOOL PRACTICES IN PORTUGAL

ABSTRACT: We present writing practices within curricular (requested by teachers) and extra-curricular (free initiative) contexts by students (ages 9-15), attending Basic Education in Portugal; data was collected by means of a national survey. These practices express a vast and dynamic relationship with writing that is (re)constructed by the individuals. Indeed, the Didactics of Writing has highlighted the necessity to understand the personal relationship that individuals (re)create with the act of writing in a more profound manner, for it contains their motivations or detachment factors that have led them to reject the practice of written verbal production. The results show a greater diversity of out of school practices that contrast with focused in-school writing practices designed to prioritize teaching-learning goals. Nevertheless, we note connecting elements between the two contexts that inform a more favourable didactic approach towards a more significant path between the individuals and writing.

Keywords: Relationship with writing; In-school and out of school writing; Writing instruction; Didactics of Writing.

\section{INTRODUCุÃO}

O ensino da língua de escolarização, principalmente da atividade de produção escrita, assumir-se-á consensualmente como uma área prioritária de intervenção em contextos pedagógicos, formativos e investigativos, a avaliar pela sua importância decisiva no combate ao insucesso escolar e numa efetiva democratização. Em Portugal, o nosso grupo de investigação ${ }^{2}$ tem-se dedicado precisamente à Didática do Português, com ênfase particular no ensino e na aprendizagem da escrita.

Com uma atuação em diversos níveis de ensino superior e não superior, temo-nos concentrado, maioritariamente, na educação básica (EB - nove anos de escolaridade, dos 6 aos 15 anos, de frequência obrigatória), ${ }^{3}$ pois, tal como outros investigadores (CUTLER; GRAHAM, 2008), consideramos determinante contribuir para uma eficaz e sólida iniciação à produção de textos escritos desde os primeiros anos de ensino formal. Para tal, procuramos congregar várias linhas de investigação sobre a escrita que, a nosso ver, se complementam e são suscetíveis de desencadear práticas mais equilibradas entre as múltiplas variáveis a equacionar: i) a complexidade e a recursividade dos processos de produção textual; ii) a especificidade de diferentes géneros de textos; iii) a importância da motivação e da relação pessoal do aluno e do professor com a escrita. Ora, estas três dimensões 
definitórias do ato de escrever - processual, social e pessoal - deverão estar contempladas em todo o processo de ensino da escrita que não queira ser restritivo, mas sim sistemático, programado, para atender a aspetos linguísticos, discursivos e afetivos, ensino caracterizado, ainda, por uma monitorização pelo professor que não ignore a relação que o sujeito desenvolve, desde cedo, com a escrita, através de processos mais ou menos conscientes.

Esta noção da "relação com a escrita" (BARRÉ-DE MINIAC, 2000), de configuração instável e ancorada ela própria na de "relação com o saber" (CHARLOT, 2000, 2013), tem merecido, portanto, o nosso investimento quer no terreno da didática investigativa quer da didática prática (CARDOSO, 2009; CORTESÃO, 2012; ROSÁRIO, 2010), por apresentar potencialidades para proporcionar condições institucionais conducentes ao estabelecimento de uma relação positiva e produtiva com a produção de escritos.

Ora, é justamente na escrita - e, muito provavelmente, na relação que com ela os sujeitos (não) estabelecem - que se identificam problemas carentes de intervenção, enunciados diversamente por vários agentes educativos, desde os professores, aos formadores, aos investigadores, inclusivamente em missão de avaliar o desempenho dos alunos a nível nacional, por meio de provas de aferição e de exames nacionais em vários anos do $\mathrm{EB}$. Nos vários relatórios das provas de aferição de Língua Portuguesa, ${ }^{4}$ por exemplo, tem sido recorrente a evidência de que é na escrita que surgem os resultados mais baixos, quando comparados com os desempenhos na "leitura" e no "funcionamento da língua", bem como a maior dificuldade de atingir um produto "muito bom", sendo a "textualização" um dos parâmetros com piores resultados, por contraponto àquele em que, na escrita, os alunos evidenciam menor dificuldade: a extensão do texto solicitado. Estes problemas de textualização evidenciados interpelam, portanto, os procedimentos de ensino que se geram nas escolas e a necessidade de se apostar em dispositivos didáticos que equilibrem as várias dimensões da escrita.

De facto, a produção escrita tem um peso muito significativo em todo o sistema educativo, mormente na avaliação, de tal modo que parece existir uma correlação muito estreita entre o sucesso de um aluno nas várias disciplinas e a sua proficiência na escrita. $\mathrm{Na}$ verdade, para escrever bem, é preciso o aluno conseguir respeitar a instrução que lhe é dada, adequar-se às finalidades da sua escrita, mobilizar informação específica das várias áreas disciplinares e dar prova de aquisição e construção de conhecimento, num registo 
que se considere adequado ao contexto escolar, num texto coeso, coerente e que respeite as normas linguísticas e discursivas em vigor. No entanto, aceder a este nível de competência escritural - em que se intricam, como vemos, as tais dimensões cognitivas e emocionais - é uma tarefa árdua, porque escrever é difícil, e, à medida que se progride no sistema de ensino, as dificuldades na escrita tendem a avolumar-se, originando atitudes de repulsa e de rejeição perante as tarefas de escrita e a cristalização de algumas representações-obstáculo (CARDOSO; PEREIRA, 2015a), como sendo a ideia de que "não se tem jeito para escrever" e de que o desempenho nas tarefas de escrita depende de uma qualquer "inspiração" incontrolável.

Por conseguinte, é percetível que os alunos estão, muitas vezes, a desenvolver representações erróneas acerca da escrita e uma relação com este "objeto" que não favorece um investimento na aprendizagem do processo de escrita de vários géneros textuais. Em contrapartida, fora da escola, existem evidências de produção escrita fértil e variada (CARDOSO, 2009; PENLOUP, 1999), muitas vezes patenteando o domínio de saberes requeridos em contexto escolar (PENLOUP, 2008). Assim sendo, as escritas extraescolares não serão, a nível textual, (sócio) (meta)linguístico, destituídas de valor para os objetivos escolares concernentes à escrita. Além disso, é necessário não esquecer que não são apenas os melhores alunos a escrever por iniciativa própria; os resistentes à escola e à escrita escolar "escondem", efetivamente, práticas escriturais nunca reveladas (CARDOSO; PEREIRA, 2015b). Como tal, os professores, estando de posse de dados sobre a produção extraescolar, poderão, em primeiro lugar, requestionar a sua imagem dos alunos enquanto escreventes e, em virtude da leitura positiva que esse requestionamento suscite, conceber e experimentar dispositivos didáticos que não ignorem a trajetória dos alunos enquanto sujeitos de escrita por livre iniciativa.

A consideração desta produção extraescolar de textos dos alunos implicará, seguramente, uma atenção mais particular às Tecnologias da Informação e da Comunicação (TIC) e à escrita eletrónica, dada a frequência massiva desta prática e a proliferação de novos géneros textuais, bem como, na sequência do que também prevê C. MacArthur (2009), o seu possível impacto no desenvolvimento da literacia dos estudantes. Por isso, em DE, torna-se relevante conhecer como é que o mundo das TIC está a influenciar a escrita dos alunos, que práticas são vivenciadas em contexto extraescolar e que interesse é que poderão ter em contexto escolar. 
Neste trabalho, vamos, então, partir de uma breve alusão às dimensões da escrita que enformam os nossos dispositivos de ação didática, para focarmos a importância de produzir conhecimento acerca do Sujeito escrevente, por reconhecermos que a noção de relação com a escrita, nas suas diferentes dimensões, que explicitaremos, é suficientemente operatória para nos fazer configurar um traçado completo e complexo dos fatores em jogo quando se escreve. Consequentemente, se, ao mobilizarmos a relação com a escrita, estamos a aglutinar os vários pontos nevrálgicos acionados antes, durante e após o processo de escrever, o conhecimento acerca dessa relação interessa à DE, não só em contextos específicos - o que permitirá um aprofundamento mais coincidente com a natureza polimórfica da "relação com a escrita" e, portanto, mais consequente na prática didática -, mas também num âmbito mais alargado, a respeito da população estudantil, em geral, e da forma como se relaciona com o escrever.

Por essa razão, e na sequência de um estudo de caso (CARDOSO, 2009), empreendemos um estudo extensivo, por meio de um inquérito por questionário a uma amostra representativa dos alunos dos anos terminais dos três ciclos do EB português -4 . $^{\circ}$ ano $\left(1 .^{\circ}\right.$ ciclo), $6 .^{\circ}$ ano $\left(2^{\circ}\right.$ ciclo) e $9 .^{\circ}$ ano $\left(3^{\circ}\right.$ ciclo). Os resultados apontam, a nível nacional, as práticas de escrita escolar e extraescolar dos alunos ao longo do EB com e sem mediação das TIC e, portanto, quais as TIC mais utilizadas pelos alunos, fornecendo indicações para se perceber que relação com a escrita estão a construir em contexto escolar e extraescolar. Neste artigo, vamos apresentar uma análise global dos dados, incidindo apenas no contraste entre práticas escriturais escolares dos estudantes - a pedido do professor de Português/Língua Portuguesa (LP) - e extraescolares, empreendidas por vontade própria do sujeito.

\section{ESCRITA DE TEXTOS, EM CONTEXTOS, POR SUJEITOS}

A escrita, enquanto atividade cognitiva complexa, implica a mobilização de competências compositivas inerentes aos processos de combinação das expressões linguísticas para produzir um texto, não podendo, no entanto, ser vista apenas como uma aplicação das regras da língua nem como uma imitação de modelos literários (PEREIRA; CARDOSO, 2013a). A escrita é um processo reflexivo, que demanda ser movido a prazer, e requer a tomada de decisões, tanto sobre o 
conteúdo, como sobre a linguagem a utilizar, existindo múltiplas alternativas para a sua construção, ao nível macro e microestrutural. O ensino da escrita passará, portanto, pela construção ou adaptação de dispositivos didáticos consistentes e bem fundamentados que prevejam o acompanhamento e a mediação do processo de escrever até à obtenção do "produto textual (considerado) final", através da realização, sistemática e estruturada, de atividades que promovam no aluno o desenvolvimento de competências nas diversas fases iterativas de planificação, textualização, reescrita e revisão da produção textual. A este nível, sabe-se que a ativação de formas de trabalho colaborativas podem potenciar as aprendizagens escriturais (GOMES, 2006; PEREIRA; BARBEIRO, 2010; SIMÕES et al., 2010).

Para além da ação educativa centrada no processo de escrita, é essencial promover a realização de atividades de produção textual em contextos reais de escrita nos quais os alunos identifiquem de forma clara uma finalidade para os seus escritos. Ao atribuírem uma intencionalidade às suas produções, imprimem-lhe uma orientação discursiva, possibilitando que "a aprendizagem da construção de textos seja de tal modo que permita aos alunos compreender o que significa o ato de escrever" (PEREIRA, 2008, p. 41).

Num tal ensino, as TIC, nomeadamente o computador, afiguram-se como adjuvantes, como demonstram C. F. Tavares e L. F. Barbeiro (2011), quer do processo de geração e gestão textual, inclusivamente por via de projetos de escrita colaborativa em rede - pesquisar/planificar, (re)escrever e rever -, quer da configuração gráfica, criação e divulgação do produto na turma, na comunidade escolar e para além dela, dependendo dos objetivos a que se proponham os escreventes. Efetivamente, se se optar pela partilha na internet, fica aberto todo um campo para a emergência e multiplicação de interações multimodais entre leitores e autores. As vantagens inerentes à facilitação processual, à escrita colaborativa coordenada, à interação, comunicação e socialização dos escritos, estes com funções e finalidades conscientes, não justificam per se, no entanto, uma "euforia", já que os resultados da investigação não associam os progressos na escrita somente ao que o computador possibilita, mas mormente ao enquadramento dessas ações oportunizadas num contexto pedagógico, promovido pelo professor, que proporcione reflexão sobre o processo - pessoal, acrescentaríamos - e maior adentramento no domínio das características e contextos de circulação dos géneros textuais em estaleiro. Dessa forma, o aluno cresce como 
sujeito-autor, ciente das possibilidades de ação por escrito à sua disposição, e escrever ganha sempre novo(s) sentido(s).

A consciência que a DE tem trazido à luz acerca de modos de trabalho mais produtivos no ensino-aprendizagem da escrita (PEREIRA, 2014) está globalmente em sintonia com os discursos programáticos oficiais e todas as medidas ministeriais que têm surgido na última década no nosso país. Efetivamente, já os programas de Português homologados em 1991 defendiam um ensino explícito da escrita, contrariando um "paradigma redacional" de práticas atomizadas, sem ligação às outras competências e saberes. O programa de 2009, em vigor até há pouco tempo ${ }^{5}$ (a que se acrescentaram as Metas Curriculares de Português do Ensino Básico em 2012), partilhava dos mesmos princípios e pressupostos, mas avançava mais arrojadamente na definição clara da escrita como componente essencial não só na aula de língua mas como transversal à vida escolar (e cívica), apontando descritores de desempenho dos alunos, orientadores de uma programação mais sustentada. Para um ensino da língua mais robusto, nos primeiros quatro anos de escolaridade, levou-se a cabo também, por iniciativa ministerial, de 2006 a 2010, o Plano Nacional do Ensino do Português (PNEP) para o 1. ${ }^{\circ}$ ciclo do EB, que deu azo a uma formação contínua sem precedentes, nos contextos da praxis, mobilizando professores das escolas e das universidades. A produção e divulgação de brochuras e de materiais didáticos (BARBEIRO; PEREIRA, 2007; PEREIRA; CARDOSO, 2013a; PEREIRA; GRAÇA, 2009) foi uma necessidade premente e tendência que, com a implementação dos programas de 2009, teve alguma continuidade (PEREIRA; CARDOSO, 2011), nomeadamente com os "Guiões de implementação" para várias competências, de que destacamos a escrita (NIZA; SEGURA; MOTA, 2011).

Os documentos programáticos e a investigação em DE sustentam, portanto, um paradigma de desenvolvimento contínuo do sujeito na produção textual, assente na recursividade, redescoberta, revisão e na relação com os outros (colegas, professores, leitores em colaboração durante o processo e para comunicar), consigo próprio (daí o tempo e lugar necessários à diferenciação pedagógica), com o texto (aperfeiçoamento, interiorização). Neste contexto, o próprio professor passa a ser encarado "como interlocutor, animador e criador de situações para melhorar a escrita, integrando-a em projetos mais latos, funcionais e investidos de significação" (FERREIRA, 2014, p. 36).

Como se torna evidente, ensinar e aprender a escrever implica a gestão de múltiplas variáveis da ordem do processo de gestação do 
texto - com a sobrecarga cognitiva que lhe é inerente -, da ordem dos contextos sociais em que os textos circulam e a que se destinam (BRONCKART, 2006), convocando o sujeito inteiro na sua disposição para a escrita e para se implicar - mais ou menos - no domínio de todo este processo. Isto significa que, à DE, não podem interessar só as características do ato de escrita nem os contextos de escrita, mas sobremaneira os sujeitos que levam a cabo o "empreendimento" da escrita e como favorecer a construção de uma relação com a escrita que suporte todo o investimento necessário na produção textual e que conduza a um maior desenvolvimento nesta competência. A DE não ignora, assim, o afeto do sujeito pela escrita, ganhando relevo a consideração de práticas da escrita das crianças/adolescentes. É por esta razão que consideramos que a noção de "relação com a escrita" é operatória no contexto didático por, justamente, nos permitir conhecer mais aprofundadamente o papel ativo do sujeito no tratamento que faz dos dados provenientes do seu meio familiar, escolar, social e, diríamos, o papel decisivo que o sujeito tem quando imerso em situações de aprendizagem formal.

\section{RELAÇÃO COM A ESCRITA}

Em alguns contextos formativos - em que, justamente, se pretendeu inverter, na prática didática, algumas rotinas de ensino da escrita que se têm revelado menos produtivas, apostando num trabalho orientado pelo ensino de géneros textuais (PEREIRA; CARDOSO, 2013b; SCHNEUWLY et al., 2004) e pela mediação do processo de escrita - destacaram-se algumas evidências de que, mesmo com um trabalho de ensino sistematizado e fundamentado, alguns alunos não "aderiram" à escrita e não se implicaram na gestão do processo escritural (PEREIRA; CARDOSO, 2010). Tendo, em alguns casos, rentabilizado as TIC, pela hipótese de contribuírem para gerar maior mobilização no aluno, permanecem, todavia, as questões relativas ao que falta fazer para levar os alunos a (querer) aprender (a escrever), quando nem as TIC, aliadas aos tais "dispositivos potentes", parecem não ser suficientes para manter um elevado nível de motivação ao longo de toda a sequência de aulas para a escrita, sentida esta, por vezes, como "saturante".

É nesta linha de raciocínio que a relação do aluno com a escrita (BARRÉ-DE MINIAC, 2008) emerge como central em todo o processo de escrita e de ensinar e aprender a escrever. Efetivamente, a dificuldade e o bloqueio na escrita que se observam em alunos 
e em adultos evidenciam quer a complexidade dos processos de escrita quer a inerente complexidade do seu ensino e aprendizagem. Paralelamente, a sociedade da informação reclama um saber escrever que dê ordem ao "caos", para a vida escolar e socioprofissional. Sem podermos, todavia, referir-nos taxativamente às causas e efeitos de certas dificuldades e de atitudes comummente apontadas como responsáveis pelo insucesso na escrita, consideramos que a noção de "relação com a escrita" é suscetível de fornecer explicações e sugerir pistas válidas para equacionar didaticamente o trabalho sobre as dificuldades de escrita, na medida em que a relação com a escrita é reconhecida como um lugar de interações complexas e evolutivas entre fatores afetivos, cognitivos e linguísticos.

A escrita não é, como sabemos, uma atividade que resulta de inspiração; antes mobiliza competências, por exemplo, ao nível dalíngua escrita, mas também atitudes, como a de decidir e se disponibilizar para escrever, pois o Sujeito implica-se e compromete-se no ato de escrita. As motivações e representações foram cedo identificadas como constituintes do que se designa por competência escritural (DABÈNE, 1987), pois moldam, por vezes de modo conflitual, a relação do Sujeito com a escrita e permitem, eventualmente, detectar o que o mesmo autor designou como "insegurança escritural" do sujeito. Nesta linha de continuidade, inscrevemos as "representações" na noção mais lata de relação com a escrita, fenómeno muito mais amplo para cuja construção concorrem todas as experiências do Sujeito com a escrita, mesmo que delas não tenha consciência. Assim, apesar do caráter abrangente que caracteriza a relação com a escrita, é possível destrinçar diferentes elementos que a constituem e que se revelam operativos porque dirigidos a fenómenos concretizáveis e observáveis, o que se torna mais viável para a consecução de desenhos investigativos e mais consequente para a prática didática (BARRÉ-DE MINIAC, 2000; CARDOSO, 2009): o investimento feito na escrita; opiniões e atitudes relacionadas com a escrita; conceções sobre a escrita e a sua aprendizagem e modos de verbalização sobre a escrita.

Globalmente, o investimento na escrita significa o interesse afetivo pela escrita, a quantidade de energia que a ela consagramos. Neste âmbito, devemos distinguir a força de investimento, isto é, a intensidade e frequência da prática de escrita e o tipo de investimento - situações de escrita e tipos de texto a que os escreventes se dedicam. A ideia de uma força de investimento forte, média ou fraca na escrita estará, portanto, ligada à dedicação do Sujeito à escrita, à medida da quantidade de vezes em que se investe a escrever. Nem sempre, no 
entanto, um fraco investimento denota rejeição pela escrita nem a violenta rejeição da escrita em contextos escolares ou profissionais poderá equivaler sempre a um investimento fraco; na verdade, talvez esconda uma força significativa de investimento noutras escritas (extraescolares), que não foi atualizada na escola, conduzindo a práticas bem-sucedidas e valorizadas, pelo menos na ótica do Sujeito.

As opiniões e as atitudes relacionadas com a escrita dizem respeito às declarações e aos comportamentos, podendo estas duas dimensões do "dizer" e do "fazer" estar ou não em consonância. De qualquer forma, enunciar uma opinião, seja qual for o interlocutor, é tomar posição - pode ser, também, de certo modo, um comportamento. Os comportamentos propriamente ditos poderão ser caracterizados inferencialmente, através da observação direta, ou pelo próprio Sujeito. Esta dimensão recobre o campo dos valores, dos sentimentos para com a escrita e seus usos, das vontades, julgamentos, expectativas para o sucesso escolar, social, profissional, o que significa que inclui o polo "valorização/ desvalorização" da escrita.

As conceções sobre a escrita e a sua aprendizagem, que os Sujeitos manifestam, revelam algumas recorrências que se vêm cristalizando nas representações-obstáculo à aprendizagem da escrita escolar (BARRÉ-DE MINIAC, 2008; CARDOSO, 2009). O modo de verbalização sobre a escrita designa a forma como os Sujeitos falam/escrevem sobre a escrita, como conseguem falar/ escrever sobre a escrita, nomeadamente, sobre o ato (complexo) de escrever, a aprendizagem da escrita e as suas próprias práticas de escrita e de aprendizagem escritural. Esta dimensão pretende trazer a lume a verbalização dos Sujeitos e perceber que dificuldades existem em, através da linguagem, falar dos procedimentos próprios da ordem do escritural. Neste âmbito, tem-se observado que, em regra, sobretudo às crianças, falta-lhes conhecimentos de metalinguagem que lhes permitam saber explicar mais os conteúdos escriturais do que os gestos (no sentido denotativo) que acompanham a produção escrita. Esta dimensão metacognitiva da relação com a escrita é fulcral no progresso de aculturação do Sujeito à ordem escritural e, quando um adulto (professor ou outro) ou um colega mais experimentado a escrever ajuda o aprendiz escrevente a verbalizar os procedimentos que leva a cabo para (re)escrever, o nível de consciência crítica sobre esse processo aumenta, sedimenta-se e torna-se transferível para outras situações. 
Em suma, em DE, a inteligibilidade da relação do Sujeito com a escrita implica, portanto, não só a identificação de representações, mas também de práticas e atitudes, e, sobremaneira, a compreensão dessas representações e práticas de forma articulada e, até, mediada por outros escreventes, nomeadamente o professor ou o investigador. Desta ênfase posta no aluno/Sujeito e na sua relação particular com a escrita, infere-se a necessidade de produzir conhecimento sobre as características que marcam a relação com a escrita a fim de otimizar o trabalho no terreno didático, isto é, a fim de favorecer a apropriação de conhecimentos e procedimentos para escrever de forma autónoma, o que significa ajudar os aprendentes a ganharem meios de se adaptarem e serem bem-sucedidos em novas situações de escrita. Isto equivale a dizer que a escola poderá - e deverá assumir-se como um agente de favorecimento de uma relação com a escrita que seja pautada pelo sentido que os Sujeitos atribuem à composição escrita, derivado das potencialidades que nela veem. Por outras palavras, a escola poderá ser um veículo de democratização, de combate à exclusão real e à simbólica.

\section{ESCRITA EXTRAESCOLAR: DUALIDADE ESCRITURAL OU ESCREVER ENTRE MUNDOS/MUROS}

Pretendemos elucidar como a relação com a escrita sugere a ideia de orientação, disposição do Sujeito relativamente à escrita e à sua prática na vida pessoal, familiar, cultural, social, profissional, designando, globalmente, opiniões, atitudes, valores e sentimentos relacionados com a escrita, sua aprendizagem e o uso que dela faz. Salientámos, ainda, como a DE, cuja função é propiciar a apropriação do saber escrever, necessita de estar de posse do conhecimento sobre a relação com a escrita para reunir melhores condições de garantir uma intervenção didática mais ajustada ao público escolar de hoje. De facto, como já vimos, temos estudado o papel e a implicação que a relação com a escrita tem com a (sua) aprendizagem e também o modo como uma relação favorável com o (saber) escrever pode ser potenciada por dispositivos didáticos (CARDOSO; PEREIRA, 2014).

Ora, a consideração das dimensões pessoais - mas também processuais e sociais da escrita - significa que, sem ignorar o que os modelos cognitivos têm salientado nem a natureza social da linguagem escrita (e, portanto, o ensino por géneros de texto), não podemos descurar a questão da motivação e da relação com a escrita que os 
alunos desenvolvem em vários contextos - pois a escola está (cada vez mais?) longe de ser o único lugar em que o jovem se acultura não só à escrita, mas também ao mundo do escrito (KLEIMAN, 2010).

Assim, consideramos dois contextos principais e abrangentes, o escolar e o extraescolar (fora da escola). A escrita extraescolar designa toda a produção escrita que tem lugar fora do quadro institucional da escola, por livre iniciativa do Sujeito. Estas práticas extraescolares de escrita radicam na nossa abordagem sociocultural e remontam, afinal, às escritas "comuns"/"vulgares", de que nos deu conta D. Fabre (FABRE, 1993; FABRE; LA SOUDIÈRE; VOISENAT, 1997), às escritas "domésticas", nos termos de B. Lahire (2004), às escritas "do quotidiano", segundo M. Dabène (1990); coadunam-se, enfim, com toda uma crescente complexidade sociocultural da escrita (BARTON; PAPEN, 2010), que continua a merecer aturados estudos, unânimes em revelar a importância e a presença múltipla da escrita multifuncional e plurissignificativa na vida das pessoas (BRANDT, 2015). São escritos de iniciativa pessoal, por um lado, às vezes inscritos em dinâmicas sociais, por outro. Podem ser escritos "livres", "compulsivos", "selvagens", "espontâneos" do Sujeito - com funções muito variadas, como a expressão do Eu, a procura de um efeito de catarse... - só para o Sujeito ou reservados a uma esfera privada de relações. Estamos, assim, a designar a escrita extraescolar na linha de um princípio de "globalidade escritural" e procurando chegar a uma definição ampla, ancorada em ângulos disciplinares diferentes - Sociolinguística, Sociologia, Antropologia, Etnologia - que continuam a chamar a atenção para a existência e a vitalidade de práticas de escrita ditas "comuns", "amadoras" (para além das profissionais, nos contextos laborais). Neste trabalho, consideramos as escritas extraescolares como as práticas de escrita livre de alunos do EB e qualificamo-las de privadas, pessoais, íntimas e, por vezes, escondidas.

Já existem dados que apontam para uma produção escritural extraescolar diversificada e abundante em alunos do EB, o que contrasta fortemente com a resistência e dificuldades em relação à escrita escolar que também vêm sendo denunciadas (CARDOSO, 2009; PEREIRA; CARDOSO, 2013c). Acresce que, em contexto livre, os alunos parecem produzir textos com significativa qualidade (CARDOSO; PEREIRA, 2008); já por injunção do professor nem sempre aderem às tarefas de escrita nem se envolvem com o mesmo interesse. Ora, perceber esta "dualidade escritural" que caracteriza a relação dos alunos com a escrita parece ser determinante para, em 
termos didáticos, se poder tirar partido dos saberes que os alunos constroem com a escrita, em contexto extraescolar, ajudando-os a fazer uma transposição para o contexto escolarizado. Nesta ótica, a questão do sujeito e do sentido que atribui à tarefa de escrita, e as investigações que procuram conhecer e interrogar os escritos que os alunos produzem fora da escola e o tipo de relação que estabelecem com eles, é determinante para o desenvolvimento da competência de produção escritural e conduz-nos à perspectiva de que a escrita na escola pode ser fator de democratização ou de exclusão, conforme se souber ou não fazer a ponte entre a língua forjada no ambiente social de cada sujeito - ou a sua língua materna - e a língua de escolarização. Podemos, assim, almejar um ensino que não continue a afastar os alunos da escrita, mas, ancorando-se no que eles já sabem e já fazem com a escrita, consiga ajudá-los a aceder a "patamares" mais complexos, formais e de maior realização.

\section{MÉTODO DE INVESTIGAÇÃO}

O quadro enunciado conduziu à constatação da necessidade da realização de um inquérito, por questionário, a uma amostra representativa nacional dos alunos dos últimos anos de cada um dos ciclos da EB em Portugal, $4^{\circ}, 6^{\circ}$ e $9 .^{\circ}$ anos, sobre as suas práticas de escrita escolar e extraescolar, com elementos suscetíveis de contribuírem para uma caracterização genérica da relação que está a ser estabelecida entre os sujeitos e a escrita nestes contextos, formal e informal. Como se depreende, os resultados que pretendemos alcançar com este estudo adquirem um valor teórico pelo seu contributo para pensar a $\mathrm{DE}$ bem como um valor prático por pretenderem vir a ser referenciais na construção de práticas mais fundamentadas e inovadoras. Além disso, havendo já estudos nacionais sobre os alunos e a leitura, ${ }^{6}$ era de notar a ausência de estudos que permitissem conhecer as práticas de escrita, considerando também a mediação das TIC.

\subsection{AMOSTRA}

Foi selecionada uma amostra nacional estatisticamente representativa de alunos dos três anos finais de cada ciclo da EB $4^{\circ}, 6 .^{\circ}$ e $9 .^{\circ}$ anos - , matriculados em escolas públicas, em Portugal continental. ${ }^{7}$ A amostra foi constituída com base nos dados mais recentes, disponíveis no Gabinete de Estatística e Planeamento da Educação/Direção de Serviços de Estatística (GEPE/DSE) do 
Ministério da Educação (ME): 267903 alunos no total, estando 105 659 crianças no $4^{\circ}$ ano; 103411 , no $6 .^{\circ}$ ano e 58 833, no $9 .^{\circ}$ ano. Preferimos uma amostra probabilística aleatória estratificada, que consistiu na divisão da população em estudo em subgrupos, por regiões do país (Norte; Centro; Lisboa e Vale do Tejo; Alentejo; Algarve), agrupamentos de escolas ${ }^{8}$ e anos de escolaridade, obedecendo ao critério da proporcionalidade dos alunos inscritos em cada subgrupo.

Foram sorteados 16 agrupamentos, correspondendo a 4048 alunos, representando 1,5\% do universo total de estudantes no EB, nos anos visados, em Portugal continental. $75 \%$ dos agrupamentos escolares constituintes da amostra localizam-se em áreas predominantemente urbanas e $25 \%$, em áreas medianamente urbanas. ${ }^{9}$ Recebemos respostas de 1588 alunos, tendo 1407 preenchido o questionário até à última página. Obtivemos, assim, uma taxa de resposta de $39,23 \%$.

\subsection{INSTRUMENTO DE RECOLHA DE DADOS: QUESTIONÁRIO ON-LINE}

Para a elaboração coletiva deste instrumento de recolha de dados, contribuíram outros, internacionais e nacionais, especificamente aqueles, usados em estudos de caso, que já haviam sido da responsabilidade de membros da nossa equipa. Foram também desenvolvidos testes-piloto, em duas fases, com o apoio de dois agrupamentos escolares, tendo-se obtido um total de 65 questionários, preenchidos em papel, e 45 questionários, já no Google Mail. Este processo de testagem junto do público-alvo não dispensou também a verificação e validação do questionário por especialistas de várias universidades.

À construção do questionário presidiu a necessidade de recolher dados sobre os dois contextos aludidos, escolar e extraescolar, para além da caracterização sociocultural dos sujeitos. Assim, o questionário "Práticas de escrita dos alunos dos $4 .^{\circ}, 6{ }^{\circ} \mathrm{e}$ 9..$^{\circ}$ anos de escolaridade" 10 era sumariamente apresentado aos alunos, tratados informalmente, destacando-se a vantagem que, para cada um, pessoalmente, o questionário traria - "conheceres melhor como escreves" - e anunciando a distinção entre as duas partes constituintes: i) Parte I - "A atividade de escrita a pedido do(a) professor(a) de Língua Portuguesa; ii) Parte II - "A atividade de escrita por tua livre vontade", respetivamente, i) perguntas sobre "o que tens escrito a pedido do(a) professor(a) de Língua Portuguesa ao longo dos anos escolares" - escrita escolar, independentemente se é feita na escola, 
nas Atividades de Tempos Livres, em casa ou noutro local; e ii) questões para saber "o que escreves sem que ninguém te peça, ou seja, por tua livre vontade, estejas na escola ou em casa".

$\mathrm{Na}$ caracterização pessoal, os alunos forneciam informações relativas às variáveis idade, género, identificação do agrupamento de escolas (inclusivamente, localidade e distrito), dois principais adultos com quem o aluno vivia (relação de parentesco ou outra, habilitações literárias e profissão/ocupação), ano de escolaridade de frequência $\left(4^{\circ}, 6 .^{\circ}\right.$ ou $\left.9 .^{\circ}\right)$, nota mais frequente na disciplina de Português.

Uma das hipóteses principais que formulamos foi a de que a população estudantil evidenciaria indícios de dualidade escritural, havendo, na escrita extraescolar, influência da escrita escolar. Quanto a esta, questionávamo-nos, por exemplo, se abundariam ainda retratos da escrita escolar fornecidos por alunos em estudos anteriores (CARDOSO, 2009; CARDOSO; PEREIRA, 2007), que configuram, essencialmente, quatro tipos de situações de escrita escolar: escrita para criar, com imaginação; escrita para contar, falando de si; escrita para provar que sabe, para ser avaliado; escrita para passar/copiar apontamentos.

As questões colocadas nas partes I e II pretendiam conhecer, quer em contexto escolar, quer em contexto extraescolar, os tipos de textos produzidos e as finalidades subjacentes, as atividades de escrita/leitura realizadas no computador, os procedimentos de escrita (antes, durante e no final de cada atividade), as dificuldades no processo de escrita, a utilidade da escrita, a motivação para a prática escritural, e o tempo a ela dedicado. Estas informações enformam, afinal, a relação com a escrita, como se sistematiza na Tabela 1. Notese que, havendo a intenção de comparação dos contextos, houve um notório paralelismo entre as questões do grupo I e as do grupo II: por vezes os itens são exatamente iguais (=); às vezes obedecem a ajustes mínimos e, portanto, ficam similares $(s)$, ou, dada a natureza da atividade, são mesmo diferentes $(\neq)$. Finalmente, com asterisco $\left(^{*}\right)$ estão assinalados os aspectos que serão objeto de análise neste artigo e que nos permitirão contrastar, em traços gerais, o que os alunos fazem com a escrita por injunção e por livre iniciativa: 
TABELA 1. Elementos da relação com a escrita observados nos contextos escolar e extraescolar

\begin{tabular}{|c|c|c|}
\hline Relação com a es & crita & \\
\hline & Escolar & Extraescolar \\
\hline \multirow{3}{*}{$\begin{array}{l}\text { Investimento feito } \\
\text { na escrita }\end{array}$} & Tipos de textos produzidos* & Tipos de textos produzidos $(=)^{*}$ \\
\hline & $\begin{array}{l}\text { Atividades de leitura e escrita } \\
\text { realizadas no computador* }\end{array}$ & $\begin{array}{l}\text { Atividades de leitura e escrita } \\
\text { realizadas no computador }(=)^{*}\end{array}$ \\
\hline & $\begin{array}{l}\text { Frequência com que o professor pede } \\
\text { trabalhos de escrita* }\end{array}$ & $\begin{array}{l}\text { Frequência com que } 0 \text { aluno escreve } \\
\text { por livre vontade }(s)^{*}\end{array}$ \\
\hline \multirow{3}{*}{$\begin{array}{l}\text { Investimento; } \\
\text { atitudes; } \\
\text { conceções sobre } \\
\text { a escrita e a sua } \\
\text { aprendizagem }\end{array}$} & Processo (antes de começar) & Processo (antes de começar) (s) \\
\hline & Processo (durante a escrita) & \multirow{2}{*}{$\begin{array}{l}\text { Processo (durante a escrita; } \\
\text { finalização do texto) }(s)\end{array}$} \\
\hline & Processo (finalização do texto) & \\
\hline \multirow{5}{*}{$\begin{array}{l}\text { Conceções sobre } \\
\text { a escrita e a sua } \\
\text { aprendizagem; } \\
\text { opiniões e atitudes } \\
\text { relacionadas com } \\
\text { a escrita }\end{array}$} & Finalidades dos textos produzidos* & Finalidades dos textos produzidos $(s)^{*}$ \\
\hline & Utilidade das atividades de escrita* & $\begin{array}{l}\text { Utilidade das atividades de escrita } \\
(\neq)^{*}\end{array}$ \\
\hline & $\begin{array}{l}\text { Fatores de motivação (estímulo } \\
\text { da vontade)* }\end{array}$ & $\begin{array}{l}\text { Fatores de motivação (estímulo } \\
\text { da vontade) }(s)^{*}\end{array}$ \\
\hline & $\begin{array}{l}\text { Sentimentos, emoções } \\
\text { e preocupações }\end{array}$ & $\begin{array}{l}\text { Sentimentos, emoções e } \\
\text { preocupações (=) }\end{array}$ \\
\hline & $\begin{array}{l}\text { Reações do aluno ao feedback } \\
\text { do professor }\end{array}$ & - \\
\hline $\begin{array}{l}\text { Modo de } \\
\text { verbalização } \\
\text { sobre a escrita }\end{array}$ & - & $\begin{array}{l}\text { Questão aberta - «Na minha opinião, } \\
\text { preciso de três "coisas" para escrever } \\
\text { um bom texto:» }\end{array}$ \\
\hline
\end{tabular}

A operacionalidade das dimensões da relação com a escrita fica evidente na tabela anterior pois se vê em que é que essas dimensões se podem traduzir (aspectos observáveis, em inquirição) e, de resto, como também se cruzam. Apesar de o "modo de verbalização sobre a escrita" só ser solicitado explicitamente numa ocasião, ele esteve, na 
verdade, sempre subjacente a todas as respostas fechadas propostas. É certo que os itens do questionário acabam por refletir discursos de origem híbrida, dos mais leigos aos meus "oficiais" - dos próprios alunos (entrevistados, no seio de estudos de caso precedentes), de professores/investigadores, dos documentos ministeriais. Todavia, destinando-se o questionário a alunos, quisemos certificar-nos de que os termos adotados espelhavam sobremaneira os seus próprios modos de verbalização sobre a escrita, de modo a serem mais capazes de gerarem identificação para respostas mais sinceras e espontâneas. A última pergunta, a tal que é a única de resposta aberta, compreendia três espaços para o aluno preencher como lhe aprouvesse; consideramos que, não obstante estar localizada na parte II, pode subsumir também a parte I. A intencionalidade, neste caso, foi a de provocar nos alunos a liberdade total de resposta sem condicionamentos impostos por opções predeterminadas, deixando, consequentemente, emergir o seu modo natural de verbalização sobre a escrita. ${ }^{11}$

\section{3- PROCEDIMENTO DE RECOLHA DE DADOS}

Depois de validado, o questionário, em versão on-line, e maioritariamente constituído por perguntas fechadas, foi apresentado às escolas pertencentes aos agrupamentos que compuseram a amostra, de norte a sul do país. Foram contatadas as direções dos agrupamentos escolares, por correio eletrônico e telefone, tendo sido destacado o ineditismo desta investigação em Portugal bem como a imprescindibilidade da participação dos alunos a fim de alcançar as finalidades previstas, sumariamente mencionadas. Uma vez tendo a autorização da direção do agrupamento e a concordância dos professores colaboradores na aplicação do questionário, cada direção de agrupamento diligenciou no sentido de que todos os alunos dos anos letivos em estudo preenchessem individualmente o questionário, em contexto de aula, com o respetivo professor habitual nesse tempo letivo, independentemente de ser o professor de Português ou não. Para tal, quando necessário, a turma era encaminhada para uma sala com computadores e ligação à internet. Recomendou-se, apenas, que os professores salientassem a investigação em curso e a importância do preenchimento sincero por parte dos alunos. De resto, o questionário seria, como se veio a verificar, autossuficiente nas orientações, estando o professor disponível para tirar alguma dúvida, caso surgisse. O período de recolha de dados decorreu no terceiro e último período do ano escolar, durante pouco mais de dois meses, entre abril e meados de junho. 


\section{ANÁLISE E DISCUSSÃO DOS RESULTADOS}

\subsection{CARACTERIZAC̣ÃO DO PÚBLICO-ALVO}

Totalizamos 1588 respondentes, dos quais 525 a frequentar o $4^{\circ}$ ano $(33,25 \%) ; 564$, o $6 .^{\circ}(35,72 \%)$ e 490 , o $9 .^{\circ}(31,03 \%):^{12} 47,70 \%$ são meninos e $52,30 \%$ são meninas, o que, em termos de género, reflete também a distribuição que ocorre no universo. A média de idades dos alunos por ano que frequentam é de 9,67 anos (desvio-padrão doravante, DP - 1,12) no $4^{\circ} ; 11,61$, no $6 .^{\circ}(\mathrm{DP}=1,04)$ e 14,65 , no $9 .^{\circ}$ $(\mathrm{DP}=1,22)$. A idade mais frequente por ano (moda) é, respetivamente, 9,11 e 14. Os casos de alunos com idades superiores ao expectável em determinado ano ou mais baixas do que o esperado são residuais.

Em relação à composição do agregado familiar, nomeadamente aos "principais adultos" com quem os jovens viviam (só podiam indicar duas opções), nível de instrução e profissão, temos um conjunto de jovens que, maioritariamente, vive com os pais $(82,18 \%)$, sendo que cerca de $23 \%$ terão completado o $6^{\circ}$ ano e entre 20 a $22 \%$ terão concluído o $9^{\circ}$. As duas profissões mais frequentes encaixam-se nos mesmos dois grupos $^{13}$ para ambos os adultos mencionados: "pessoal dos serviços e vendedores" (adulto 1: 26,29\%; adulto 2: 19,20\%) e "operários, artífices e trabalhadores similares" (20,27\% e 31,95\%, respetivamente).

Considerando a nota mais frequente à disciplina de Português, os dois maiores grupos dos alunos inquiridos coincidem com os que declaram um desempenho "satisfatório" ("satisfaz", 33,09\%) ou "Bom" (33,19\%), havendo a registar 8,99\% de "Não satisfaz" (nota negativa) e $12,10 \%$ de "Muito bom". É preciso notar, contudo, que $63,38 \%$ das declarações de nota negativa ocorrem em alunos do $9^{\circ}$ ano, os mais velhos, portanto, à saída da EB; por oposição, as notas melhores, "Muito bom", abundam no $4^{\circ}$ ano $-54,97 \%$ das quais correspondem a alunos deste nível de ensino, os mais novos. Apesar de a comparação ao longo dos anos escolares não ser nosso objetivo neste artigo, ${ }^{14}$ não podemos deixar de notar como as notas em LP tendem a ser melhores quanto menor o nível de escolaridade. Se considerarmos a distribuição das notas consoante o género, apercebemo-nos de que são as meninas que têm notas mais elevadas (424 têm Bom/Muito Bom vs. 291 rapazes) bem como são os rapazes que, em número superior, obtêm negativa (86 vs. 56).

\subsection{PRÁTICAS DE ESCRITA ESCOLAR E EXTRAESCOLAR}

\subsubsection{TIPOS DE TEXTOS PRODUZIDOS}

A primeira questão da parte I implicava que o aluno trouxesse à sua mente as práticas escolares em LP; inevitavelmente, os sujeitos teriam 
mais facilidade em basear-se no ano letivo em curso, mas a formulação, no passado, posicionou-os, desde logo, em atitude de rememoração de toda a vida escolar em LP. Solicitava-se, assim, a indicação de frequência de escrita de 28 "tipos de texto" ${ }^{15}$ com a possibilidade de acrescentar outros, ${ }^{16}$ numa escala de Likert com os seguintes valores - muitas vezes, algumas vežes, raramente, nunca e "não me lembro/não sei". No gráfico 1 , as colunas evidenciam os valores para "muitas vezes" em ambos os contextos, escolar e extraescolar, como será aqui a nossa opção:

GRÁFICO 1. Tipos de textos produzidos - contexto escolar e extraescolar

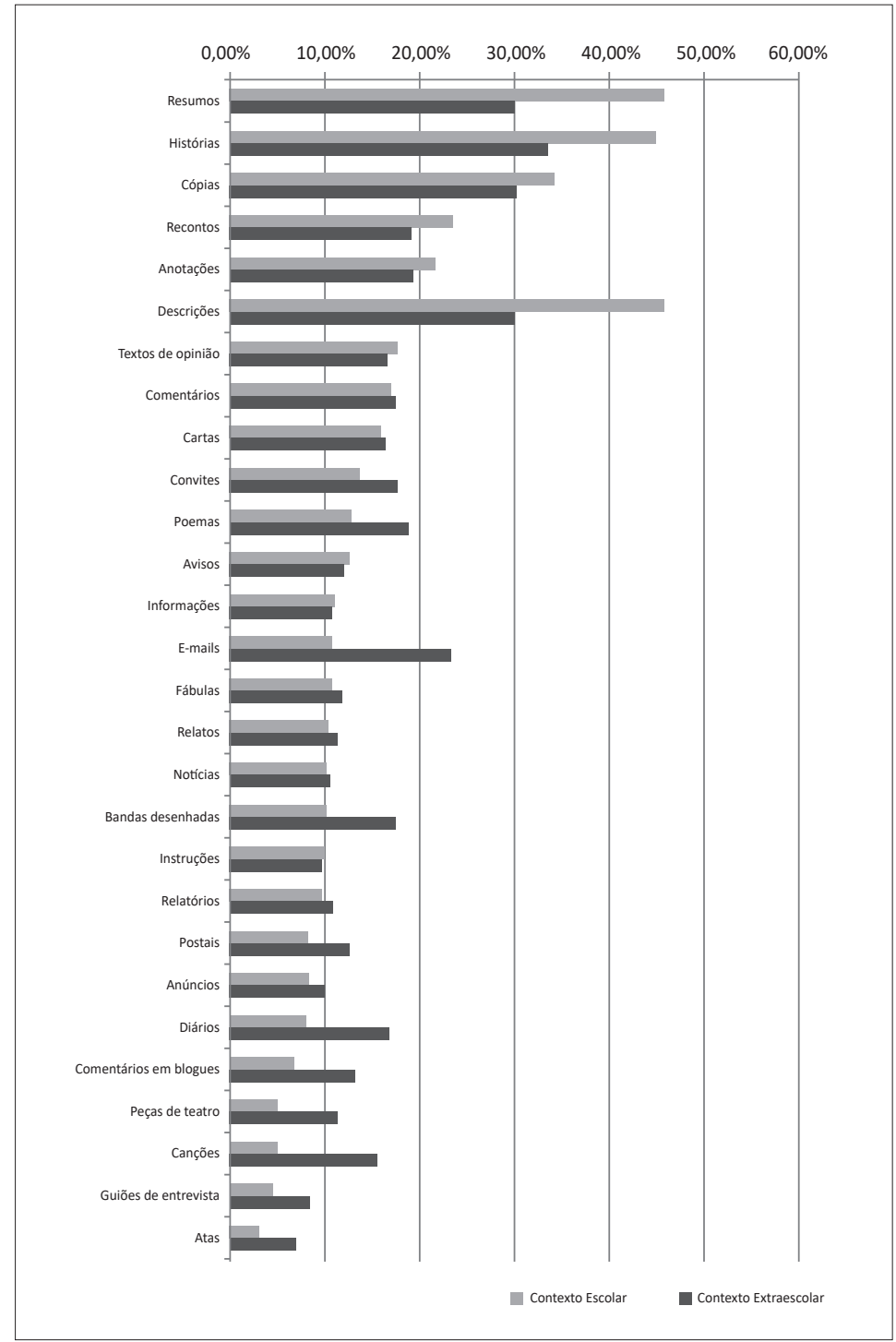


Como é possível verificar, a panóplia de textos considerados abarca várias lógicas:

i) géneros mais marcadamente escolares (resumos, cópias, anotações, relatórios), sendo estes híbridos nas textualidades e na exigência compositiva - resumos e relatórios requerendo textualização mais abundante, os primeiros, mais expositivos; os segundos, mais narrativos; cópias apenas demandando a transcrição e o esforço físico de redação e anotações por tópicos, esquemas, frases curtas, eventualmente (uma escrita menos compositiva);

ii) géneros predominantemente narrativos e outros argumentativos - histórias, recontos, fábulas, relatos, notícias, diários e atas, concretizando vários modos de narrar, com diferentes finalidades; e textos de opinião e comentários, com maior prática argumentativa. De entre estes, vários contextos de circulação estão patentes: talvez o mais escolar, no caso dos recontos e dos textos literários, o extraescolar/pessoal, para os diários, e diferentes contextos socioprofissionais, para as notícias e as atas;

iii) textos que são validados escolarmente por outras razões como: a sua literariedade diversa (peça de teatro e escrita poética poemas e canções), multimodalidade (banda desenhada - BD), pela predominância de mais tipologias textuais frequentes injuntiva (instruções, anúncios, avisos), expositiva (informações), dialogal (guiões de entrevista), descritiva (descrições);

iv) produções com finalidade comunicacional evidente - cartas, convites, e-mails, postais, comentários em blogues.

De forma a possibilitar uma comparação mais eficaz entre contextos, não quisemos incluir, no contexto extraescolar, outras práticas eventualmente existentes, associadas mais a passatempos, por exemplo (palavras que agradem, mensagens em código, frases giras, máximas, expressões, anedotas inventadas, caderno de dedicatórias, etc.), de modo que optamos por práticas mais suscetíveis de serem comuns aos dois mundos escriturais (CARDOSO, 2009).

Observamos que, em contexto escolar, se destacam grandemente os resumos, as histórias e as cópias, no que já esperávamos abundasse dentro da escola: eventual escrita para aprender, narrativa e atividade de escriba e não de autor. Essas práticas não parecem, no entanto, destituídas de valor para os sujeitos, que as replicam livremente, embora menos. Têm destaque fora da escola escritos com múltiplas funções: poéticos (poemas e canções), comunicativos (emails; comentários em blogues), multimodais (BD), intimistas e reflexivos (diários). 
Há, de resto, uma série de práticas que ocorrem muito mais fora da escola do que na escola, a validar a relevância dos contextos não escolares (KLEIMAN, 2010), onde a vida se vive tanto por escrito: atas, guiões de entrevista, canções, peças de teatro, comentários em blogues, diários, anúncios, postais, relatórios, $\mathrm{BD}$, e-mails, poemas, convites, para citar os mais evidentes. Nota-se, ainda, como o mundo escolar apresenta mais desequilíbrios do que o mundo extraescolar, o que talvez seja normal, porque no extraescolar se vive a vida "verdadeira" e, no escolar, a "fingir", sem lugar para a miríade de práticas fora da escola, mas com maior aposta naquilo que as entidades oficiais destinam como prioritário. A julgar pelas "certezas" reveladas pelo gráfico, há um claro investimento na escrita para contar, no escrever para aprender ou, hipoteticamente, para provar que sabe e ser avaliado, oscilando-se entre práticas compositivas e não compositivas (como a dos apontamentos - anotações). Poderíamos comentar, estranhas certezas, dados os enormes debates em que sempre se vê envolvida a Educação e, especificamente, as decisões curriculares...

\subsubsection{ATIVIDADES DE LEITURA E ESCRITA REALIZADAS NO COMPUTADOR}

GRÁFICO 2. Atividades de leitura e escrita realizadas no computador - contexto escolar e extraescolar

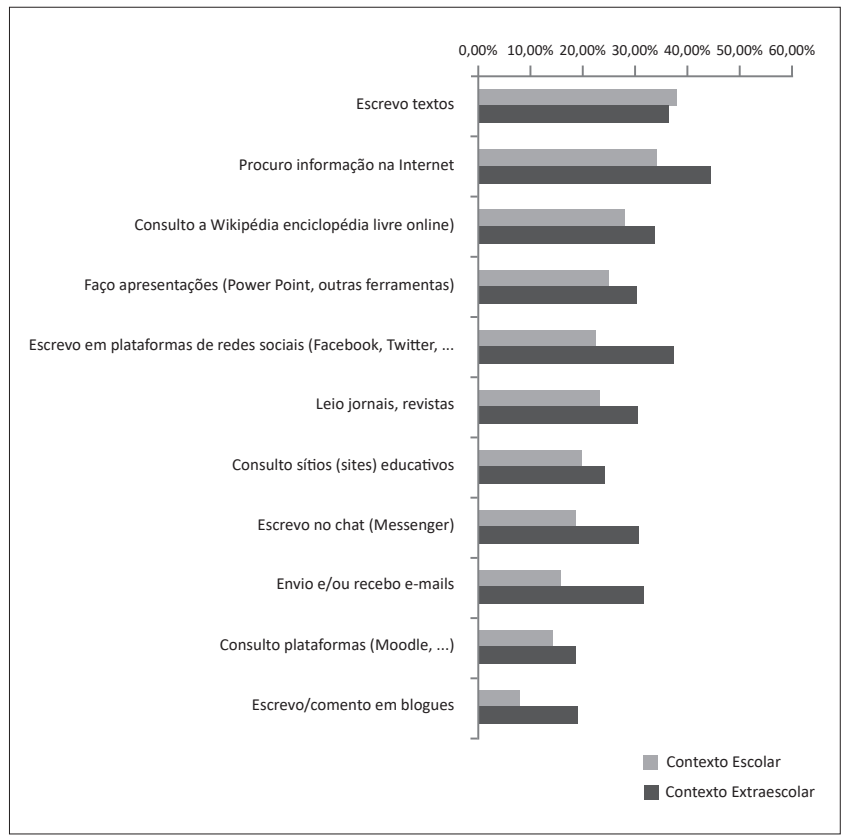

A hipótese da utilização generalizada e diversificada do computador em contexto extraescolar confirma-se pela análise do 
gráfico 2 que patenteia como, à exceção da escrita de textos, todas as outras práticas são mais frequentes fora da escola.

Não é motivo de surpresa que, efetivamente, os alunos usem mais o Moodle e afins fora da aula (o ensino a distância faz parte do objetivo de criação destas plataformas), alimentem conversações e interajam socialmente, mandem e-mails, consultem sítios educativos (nas aulas, dispõem do apoio do professor), leiam sobre assuntos do seu interesse. No entanto, pode dar-nos que pensar o fato de que o aluno está mais vezes, em contexto extraescolar, em situação de consulta no caos informacional da internet multimodal, entregue - não sabemos se sozinho - à abundância informacional. Considerando aqueles que são trabalhos de casa habituais no EB - "pesquisar informação sobre..." -, também é legítimo perguntar até que ponto o aluno terá, para o contexto extraescolar, feito declarações exclusivamente acerca das práticas de sua iniciativa ou estas terão sofrido algum contágio das anteriores. Seja como for, por muito que o aluno empreenda atividades sociais e de pesquisa de livre vontade, acreditamos na escola e no seu papel unificador e integrador dos saberes, para além das possibilidades de socialização humana presencial. A propósito, sabe-se, hoje, que é preciso que na escola tenham lugar atividades de monitorização da pesquisa, da gestão e do tratamento honesto e eficaz da informação (VEIGA, 2014), já para não invocar a necessidade de aprender a gerir relações humanas e emoções (OLIVEIRA, 2011).

\subsection{3. - FREQUÊNCIA DE ESCRITA}

GRÁFICO 3. Frequência de escrita escolar e extraescolar

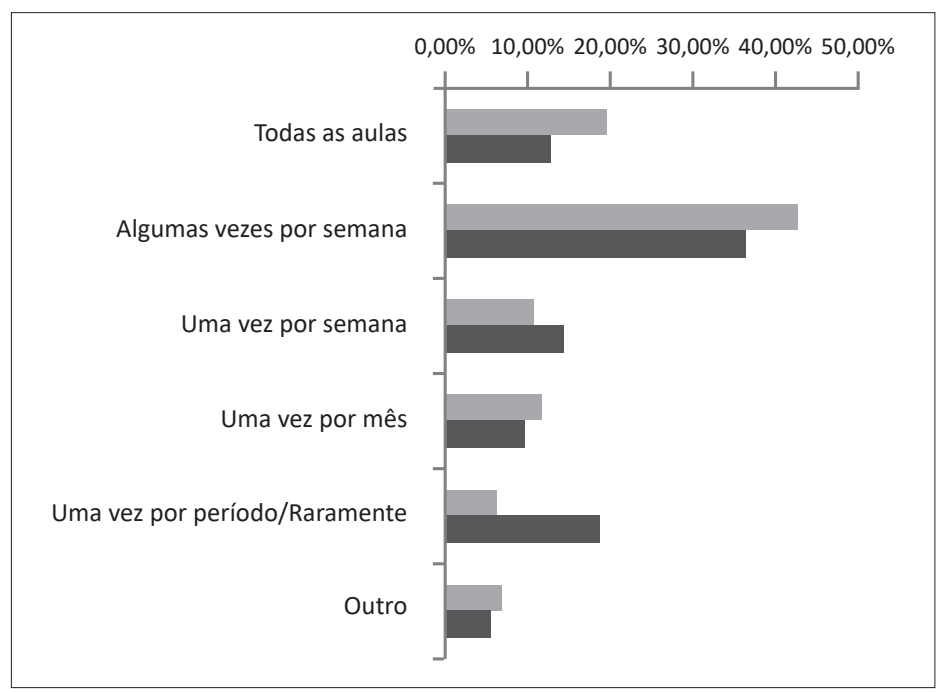


A maior concentração de alunos verifica-se, em ambos os contextos, no indicador "algumas vezes por semana". Escrever "uma vez por semana" é mais habitual fora da escola, enquanto que "todas as aulas" é mais comum na escola do que, informalmente, "todos os dias". Esclareça-se que "Todas as aulas" quase só no $4^{\circ}$ ano pode equivaler a "todos os dias", uma vez que, nos demais anos, as cargas horárias recomendadas ministerialmente variam de 8,25 horas, no $6 .^{\circ}$ ano, a 3 horas de Português por semana, no 9..$^{\circ}$, horas que raramente são distribuídas diariamente, mas que, em regra, se traduzem em 2 a 4 encontros semanais, organizados em blocos de 90 minutos.

$74,9 \%$ dos jovens escrevem livremente numa frequência que varia de todos os dias a uma vez por mês; em contrapartida, $19,17 \%$ declaram que raramente escrevem livremente. ${ }^{17} \mathrm{O}$ menor investimento na atividade de escrita livre cresce com a progressão no EB: quanto mais velhos são os alunos, menos vezes escrevem; aliás, na escola acontece o mesmo, isto é, mais de metade dos alunos do 9. ${ }^{\circ}$ ano $(51,32 \%)$ escreve entre uma vez por semana, por mês ou por período. Esta comparação por anos, muito reveladora e interessante, será, no entanto, alvo de tratamento noutro contexto. ${ }^{18}$

\subsection{4. - FINALIDADES DOS TEXTOS PRODUZIDOS}

GRÁFICO 4. Finalidades dos textos produzidos - contexto escolar e extraescolar

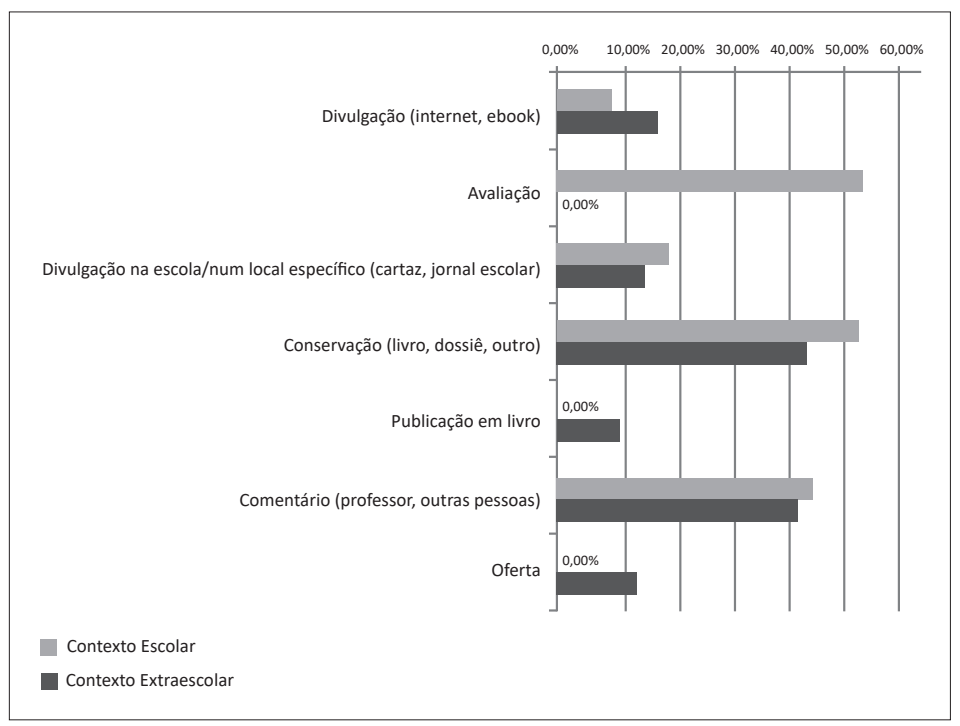


Os indicadores previstos nesta questão condensam várias finalidades para os escritos obrigatórios e livres, quase todas comuns a ambos os contextos e apenas três consideradas exclusivas unicamente de um: a "avaliação" só incorporou as hipóteses para o contexto escolar; a "publicação em livro" e a "oferta", extraescolar (daí os valores "zero" no gráfico 4).

As finalidades adstritas aos textos obrigatórios e livres variam de objetivos relacionados com a avaliação/apreciação e/ou acompanhamento do processo (feedback, comentário) à classificação do produto textual (obter uma nota), a outros conformes à natureza social dos textos, concretizando a sua divulgação em diferentes suportes - confinados a estruturas físicas ou institucionais, restringidos à comunidade escolar ou inscritos na infinitude da internet, passando por objetivos arquivísticos segundo os quais, por diversas razões ou ambições pessoais, os sujeitos pretendem guardar os textos; podem, neste caso, servir de registos de indícios de progressão, testemunhar histórias de vida, ou, mesmo, almejar uma futura publicação em livro, para só mencionar alguns. A escrita, objeto de desejo pessoal, criação única, pode também ser vista como um presente a oferecer a alguém, pelo que também essa finalidade é contemplada. As finalidades previstas não ignoram, portanto, a monitorização dos processos nem a socialização dos produtos, nos meios que façam mais sentido para os sujeitos.

No que diz respeito ao contexto escolar, é inquestionável a supremacia das práticas de avaliação, sumativa, primeiro, e eventualmente formativa, a seguir. As práticas de conservação e de socialização de um objeto escritural potencialmente afetivo são em muito menor número.

No contexto extraescolar, é, uma vez mais, notória uma maior dispersão dos resultados pelos indicadores. Prevalece o objetivo associado à história de vida do sujeito, a lembrar, afinal, como a escrita está plenamente acoplada ao desenvolvimento identitário. A segunda finalidade mais frequente é bastante promissora, do ponto de vista pedagógico da intervenção na escrita - comentário (professor, outras pessoas); de entre os alunos que aí se inserem, 23,3\% confessam confiar no seu professor (será de LP) para lhe mostrarem uma produção livre, acusando essa atitude um reconhecimento do professor, talvez autor, se não, pelo menos, autoridade em matéria de escrita. Escrever para outros lerem - seja para dar opinião seja para receberem o texto de presente, ou para uma divulgação mais vasta é significativo para os sujeitos, ficando uma vez mais patente o elo dinâmico “eu, a escrita e os outros” (CARDOSO; PEREIRA, 2014). 


\subsubsection{UTILIDADE DAS ATIVIDADES DE ESCRITA}

GRÁFICO 5. Utilidades das atividades de escrita escolar

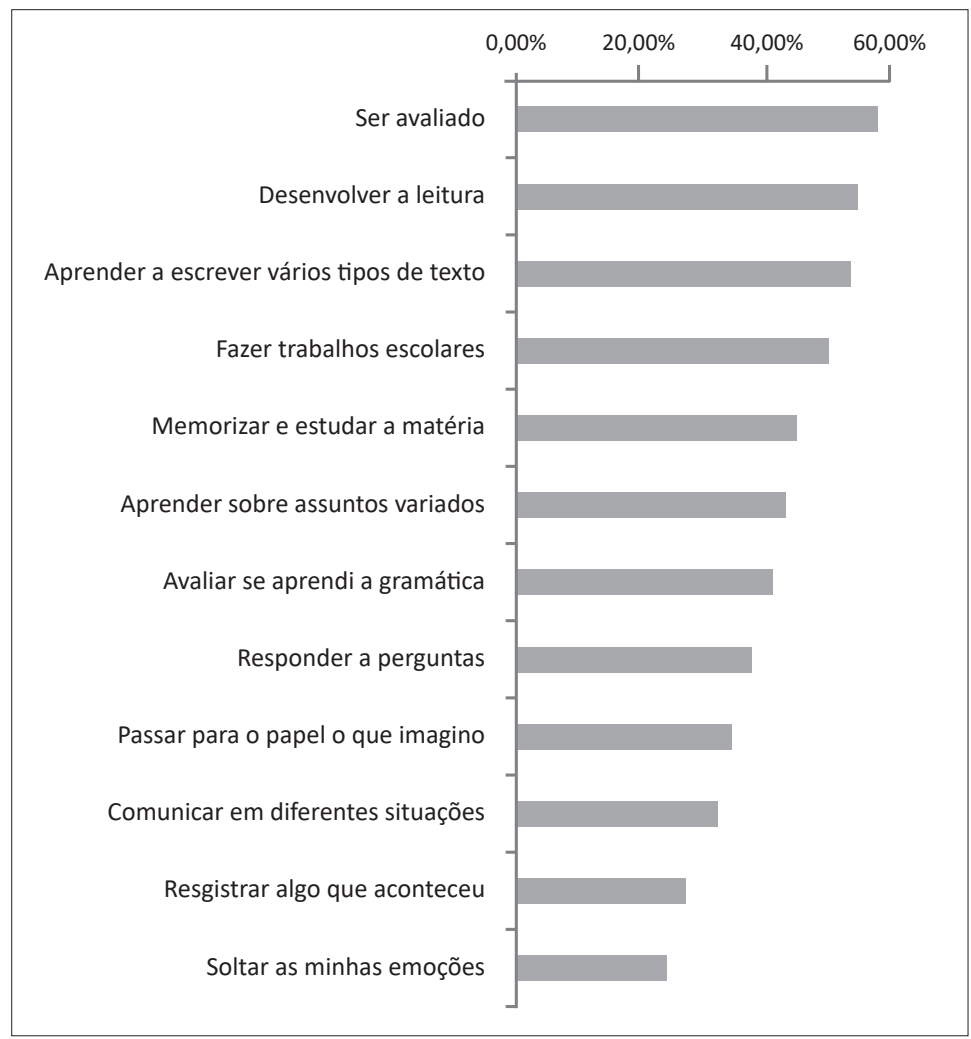

À utilidade visionada para a escrita obrigatória (gráfico 5), estão subjacentes várias conceções de escrita cuja conciliação pedagógicodidática defendemos, de forma articulada e sustentada, como sejam, a relação gramática-escrita, imprescindível quando está em jogo a gestão processual e a revisão textual, por exemplo; escrita-leitura (mais vezes explorada como leitura suscitadora de temas e de conteúdos do que como mentora da arquitetura textual); escrita como atividade pessoal, associada a fins catárticos, à imaginação (eventualmente, seu desenvolvimento); a conexão escrita-aprendizagem, escrita-fixação/ estabilização (OLSON, 2006); escrita de vários géneros textuais, eventualmente comunicativos ou escolares.

$58,06 \%$ dos estudantes declaram que a escrita serve para serem avaliados. Contudo, visiona-se um relativo equilíbrio entre a grande maioria dos indicadores - amplitude de 34,03\%; especificamente de "Desenvolver a leitura", segunda opção mais escolhida, a "Comunicar 
em diferentes situações", décima e antepenúltima opção, verifica-se uma amplitude de 22,61\%; destacam-se, por esta ordem, a relação com a leitura, a diversidade textual e a escrita para realizar trabalhos escolares (novamente, ser avaliado). Registar acontecimentos ou soltar emoções são as "utilidades" menos comuns na escola.

Em contexto livre (gráfico 6), a verbalização dada aos indicadores de "utilidade" tinha de ser necessariamente diferente, repercutindo funções anteriormente declaradas por adolescentes, que percebemos serem-lhes muito "caras". O equilíbrio entre indicadores é ainda mais visível (amplitude de 24,52\% entre os vários indicadores), destacando-se "soltar a imaginação", afinal tão pedida em contexto escolar. A liberdade de escrita ( $2^{a}$ opção com mais adeptos) não parece invalidar a prática que os sujeitos valorizam como útil $\left(3^{\mathrm{a}}\right)$. Seguem-se funções relacionadas com a formação da personalidade, o crescimento interior do sujeito - desabafar, expressar-se, registar eventos importantes para si, comunicar, partilhar, descontrair. Mostrar aos amigos aparece aqui como a utilidade menor, não sendo, portanto, com certeza, o móbil do investimento, mas podendo ser, como já vimos, um fim expectável, caso o sujeito venha a ter esse desejo.

GRÁFICO 6. Utilidades das atividades de escrita extraescolar

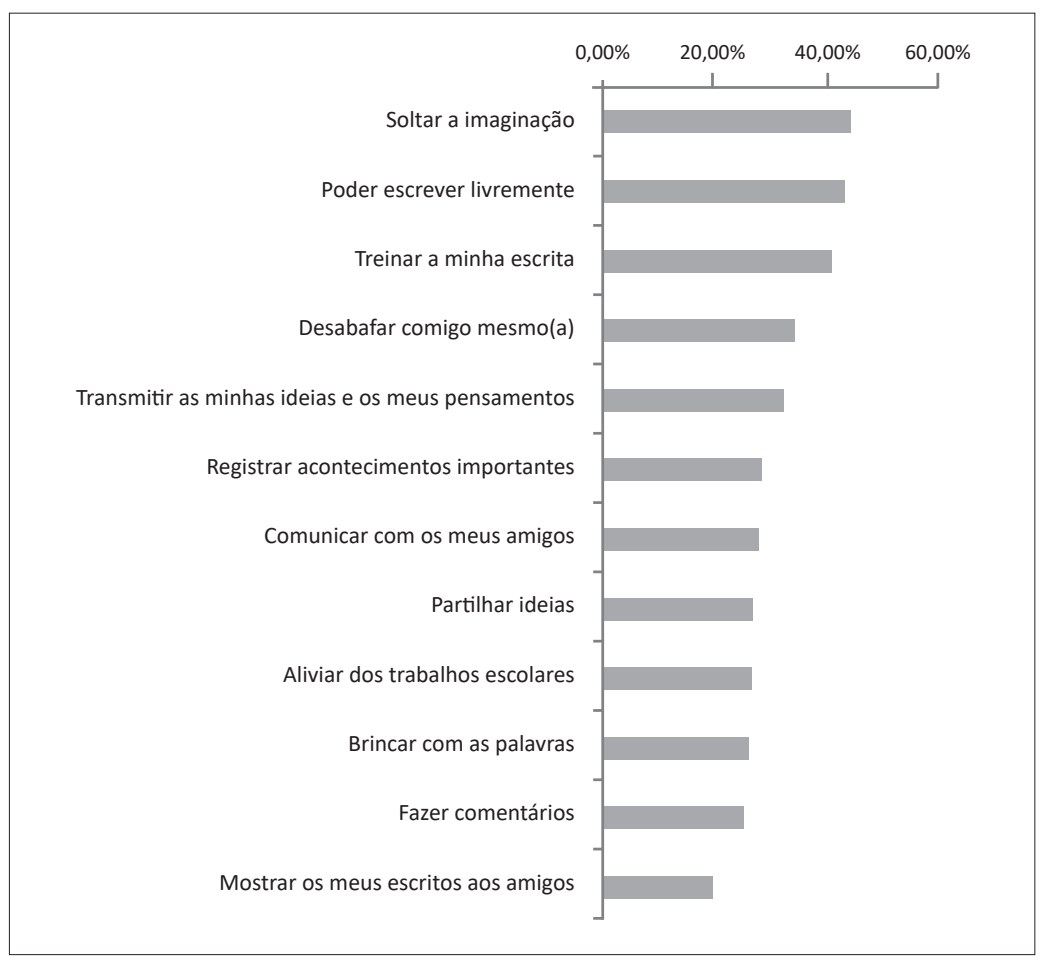




\subsubsection{FATORES DE MOTIVAC̣̃̃ (ESTÍMULO DA VONTADE)}

\section{ESCOLAR}

GRÁFICO 7. Fatores de motivação para a escrita escolar

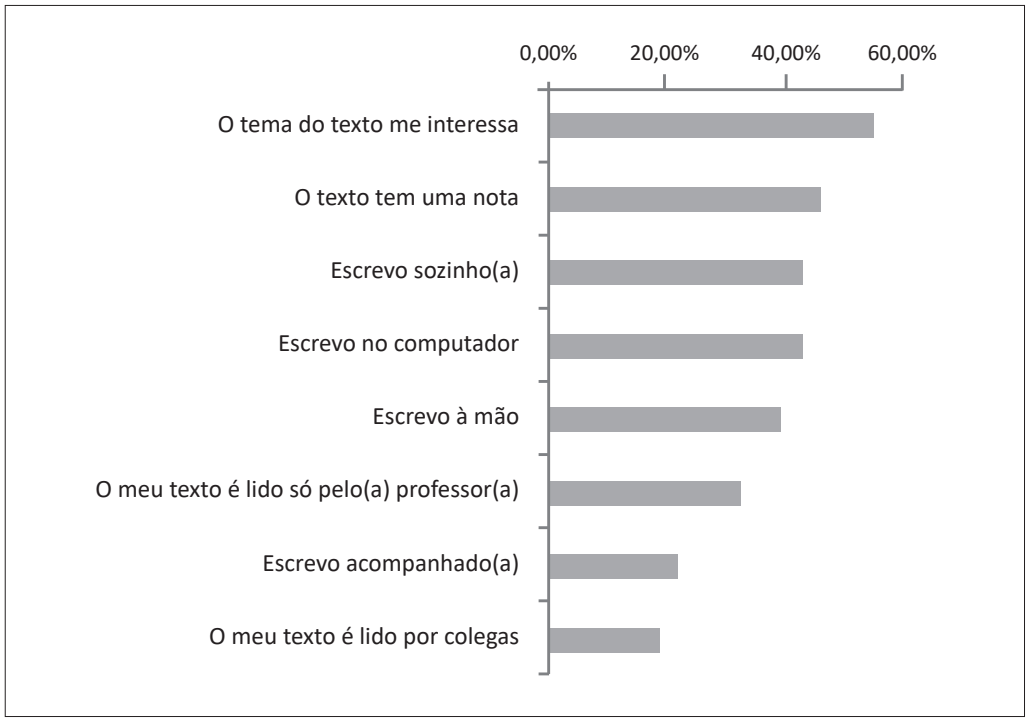

Respeitando a diferença natural entre os contextos, os indicadores para estas questões foram ligeiramente diferentes, ainda que, em ambos, se focasse a questão do meio (suporte) usado para escrever, a forma social de trabalho (em solidão ou em colaboração), a exposição dos escritos a potenciais leitores próximos ou desconhecidos, por exemplo. No fundo, em comum consideramos aqueles indicadores que se referem à natureza pessoal, social e processual da escrita, nestes últimos casos, partindo da hipótese de que o computador pode ser um facilitador; gostaríamos, por conseguinte, de aferir se os alunos acusam essa consciência.

Mais de metade dos alunos fica com mais vontade de escrever quando o tema lhe interessa (55,65\%); seguidamente vem a recompensa da atribuição de uma nota $(46,53 \%)$ e a responsabilidade individual por esse produto a avaliar $(43,6 \%)$. O fato de a escrita ser ou não feita a computador aparece em $4^{\circ}$ lugar $(43,32 \%)$, não parecendo, então, ser absolutamente determinante na adesão dos alunos; aliás, pouco menos alunos $(39,58 \%)$ preferem escrever à mão. $\mathrm{Na}$ escola, parece notar-se alguma resistência ao trabalho colaborativo $(22,26 \%)$ e à exposição da escrita individual aos outros (18,87\%). Estarão, talvez, os alunos marcados por práticas de socialização que valorizam uns escritos em 
detrimento de outros, pela sua qualidade (escolar), indicando-os como exemplos a seguir? $\mathrm{Na}$ realidade, pressentimos que estes sujeitos, talvez à semelhança de outros, teriam histórias a contar.

\section{EXTRAESCOLAR}

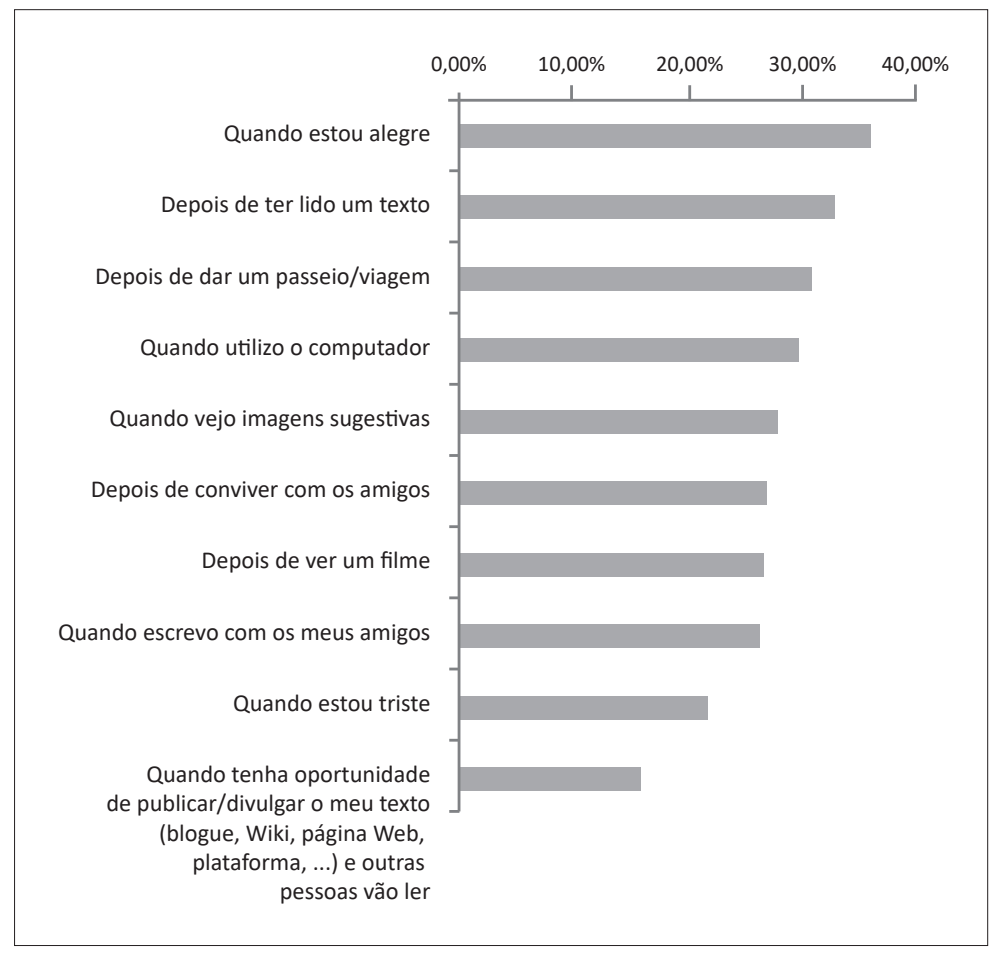

O estado de espírito, sobretudo de alegria, é o maior motor de escrita para a nossa amostra (36,23\%), seguindo-se, numa distribuição mais homogênea, a leitura como "inspiração" (32,93\%) e uma viagem ou passeio $(30,94 \%)$. Curiosamente, também neste quadro é o computador que ocupa o $4^{\circ}$ lugar $(29,77 \%)$, a que se seguem outras atividades motivantes/incitadoras, que incluem ações individuais ou em grupo (ver imagens, conviver, ver um filme). A escrita com os amigos $(26,33 \%)$ e a publicação não são, de forma expressiva, os motivos que fazem os alunos escrever.

\section{CONSIDERACִÕES FINAIS}

A DE tem salientado a relevância de conhecer mais aprofundadamente a relação que os alunos (re)constroem com 
a escrita. $\mathrm{Na}$ realidade, tem sido demonstrado que os fatores motivacionais inerentes à relação pessoal com a escrita têm um papel decisivo na implicação do aluno no seu processo de apropriação da competência de produção escrita, razão por que consideramos premente dar continuidade a esta linha de investigação que enfoca o Sujeito e as suas práticas.

O questionário realizado com vista à caracterização das práticas de escrita das crianças e adolescentes do EB em Portugal trouxe dados robustos, que não contrariam os nossos anteriores estudos de caso, para o conhecimento da relação dos alunos do EB com a escrita, nomeadamente acerca das "escritas emergentes". Nesta parte, resumidamente, focaremos essas práticas emergentes e as "emergências de escrita" que daí se nos afiguram, do ponto de vista pedagógico-didático.

Relativamente ao investimento escritural, encontramos maiores desequilíbrios entre "tipos de textos" no contexto escolar, contrastando com uma maior variedade de escritos no contexto extraescolar - na escola, erguem-se, com maior frequência, os textos ligados a objetivos de aprendizagem, muitos demandando apenas a ação de copiar; no contexto extraescolar, prevalece uma escrita mais diversa, relacionada com fins de comunicação, criação (muito associada à narração, textualidade abundante na escola também) e reflexão. Quanto às atividades de leitura e de escrita no computador, os dados não revelam um uso "eufórico" deste instrumento. Verificase uma maior utilização do computador em contexto extraescolar; em contexto escolar é mais utilizado para a "escrita de textos". Fora da escola, destacam-se a "procura de informação na internet" e a "e-escrita" em plataformas. Seja como for, considerando que o uso do computador é quase sempre superior no contexto livre, poderemos sugerir que é possível, na escola, explorar o seu potencial de uma forma mais produtiva, guiada, adjuvante dos processos escriturais. Estamos conscientes, porém, de que modos de trabalho didático nestas competências - que atendam às especificidades da leitura e escrita escolar - são mais determinantes do que a quantidade de textos lidos/escritos com ou sem computador.

O amplo acesso à informação que caracteriza o contexto extraescolar sugere também a necessidade de repensar práticas na escola-pareceque urge a passagem deum modelo predominantemente de "exposição e de cópia de informação" para formas de trabalho mais focadas em "pôr ordem no caos informacional", ajudando os alunos a gerirem e a organizarem os conteúdos, por via escrita multimodal e multifuncional. 
Aglutinando as dimensões relativas às opiniões e atitudes para com a escrita bem como as conceções relativamente à sua aprendizagem, identificamos, no contexto escolar, a avaliação como denominador comum, constituindo-se simultaneamente em finalidade, utilidade e motivação para a escrita. O trabalho escritural escolar motiva se tiver a compensação de uma nota - dependendo, em primeiro lugar, do tema; o texto serve para ser avaliado e é assim que é útil.

Inquirindo as finalidades, a utilidade visionada para as práticas de escrita e os elementos motivadores do escrever, percebemos, globalmente, focos mais efusivos nas escolhas escolares e uma maior dispersão e equilíbrio entre as opções relativas ao contexto extraescolar, talvez assim reveladoras da liberdade que o caracteriza.

Advogando um ensino integrador das dimensões processuais, sociais e pessoais da escrita, parece-nos que os resultados obtidos reforçam as seguintes prioridades - as tais "emergências escriturais":

i) a escrita afigura-se predominantemente como uma atividade solitária, tendo sido identificadas algumas resistências a uma escrita colaborativa escolar - apostar, nestes casos, em mecanismos de avaliação formativa, que beneficiem e premeiem o processo e o produto da colaboração parece fundamental;

ii) as motivações pessoais, associadas a vivências, sentimentos e a objetivos que contribuem para o desenvolvimento identitário, influenciam a vontade de escrever em ambos os contextos - uma maior ligação entre géneros textuais escolarmente valorizados e solicitados comummente e "temas vitais" para os jovens faz-se necessária. Além disso, apesar de alguns indícios de dualidade continuarem a surgir, são visíveis os liames que, a este nível, se destacam como pontes entre o contexto escolar e extraescolar: a) o professor é um interlocutor privilegiado e substancialmente preferido no contexto obrigatório e livre, salientando-se a sua importância no desenvolvimento da produção escrita; b) "soltar a imaginação" é exigido na escola, mas mais provável e frequente fora, o que leva a repensar os moldes em que a imaginação (não) é estimulada escolarmente, mas, paradoxalmente, avaliada, bem como a perspectivar outras formas de acolhimento das "escritas da imaginação" sem constrangimentos escolares, os quais poderão fazer mais sentido quando do ensino de géneros mais "formais"; c) obrigatoriamente e por livre iniciativa, os alunos acusam uma necessidade e vontade inata de aprendizagem e de progressão, que a escola precisa de aproveitar e rentabilizar - a maior 
homogeneidade e distribuição pelas várias hipóteses relativas à utilidade das atividades de escrita a pedido do professor de LP é indício disso mesmo, de uma importância que se reconhece à escrita como meio (de aprender, de progredir) e fim (revelação do aprendido, vivido...);

iii) os "escritos sociais", orientados para a comunicação e para a ação por escrito, não são predominantes nas práticas escolares mais constantes; os dispositivos de socialização - divulgação ou a publicação - apresentam percentagens mais reduzidas. Fora da escola, o aluno toma mais frequentemente a palavra para agir por escrito. A escola precisa, então, de se afirmar no seu potencial formador para a escrita como "ação social", nomeadamente em contextos mais formais.

Se os resultados deste inquérito nacional nos revelam diferenças naturais entre dois contextos necessariamente distintos, permitem-nos também corroborar como toda esta dinâmica de escrita livre é gerada e alimentada com conexões visíveis ao mundo escolar - neste, ainda predominando situações típicas que colocáramos como hipótese, mas, sem dúvida, agora um panorama escolar escritural mais completo e complexo. Os "focos" e os "desequilíbrios escolares", por outro lado, conduziram-nos a extrair pistas para modelizar intervenções didáticas que não entrem em rutura com o mundo pessoal e social dos sujeitos, antes os ajudem a incorporar saberes mais ou menos intuitivos e a torná-los mais explícitos e mais sólidos, porque inseridos em contextos "protegidos" pela necessária monitorização escritural, para que os alunos parecem estar naturalmente predispostos.

\section{REFERÊNCIAS BIBLIOGRÁFICAS}

Barbeiro, L. F.; Pereira, L. A. Pnep. O ensino da escrita. A dimensão textual. Lisboa: ME - DGIDC, 2007.

BARRÉ-DE MINIAC, C. Le rapport à l'écriture: aspects théoriques et didactiques. Villeneuve d'Ascq (Nord): Presses Universitaires du Septentrion, 2000.

BARRÉ-DE MINIAC, C. Le rapport à l'écriture: une notion à valeur euristique. Diptyque 12. Le rapport à l'écrit: un outil pour enseigner de l'école à l'université, p. 11-23, 2008.

BARTON, D.; PAPEN, U. The Anthropology of Writing. Understanding TextuallyMediated Worlds. London: Continuum, 2010.

BRANDT, D. The Rise of $\mathbf{f}$ Writing. Redefining Mass Literacy. Cambridge: Cambridge University Press, 2015. 
BRONCKART, J.-P. Actividade de linguagem, discurso e desenvolvimento humano. Campinas, SP: Mercado das Letras, 2006.

CARDOSO, I. A relação com a escrita extra-escolar e escolar. Um estudo no Ensino Básico. Tese de Doutoramento. [s.l.] Universidade de Aveiro, 2009.

CARDOSO, I.; PEREIRA, L. Á. A relação dos alunos com a escrita (extra-) escolar - uma experiência de investigação. Aprender. Comunicação e Educação. Educar para os Media, v. 31, p. 94-109, 2007.

CARDOSO, I.; PEREIRA, L. Á. A escrita livre dos alunos: que interesse para o Professor de Português? In: CARDOSO, I.; MARTINS, E.; PAIVA, Z. (ed.). . Actas do Colóquio "Da Investigação à Prática: Interacções e Debates”. Aveiro: Departamento de Didáctica e Tecnologia Educativa, Universidade de Aveiro. (Editado em CD-ROM), 2008.

CARDOSO, I.; PEREIRA, L. Á. A relação de adolescentes com a escrita: potencialidades didáticas de uma oficina sobre a escrita realizada em contexto escolar. Indagatio Didactica, v. 6, n. 4, p. 78-95, 2014.

CARDOSO, I.; PEREIRA, L. Á. A relação dos adolescentes com a escrita extracurricular e escolar - inclusão e exclusão por via da escrita. Trabalhos em Linguística Aplicada, v. 54, n. 1, p. 79-107, 2015a.

CARDOSO, I.; PEREIRA, L. Á. Le rapport à l' écriture extrascolaire et scolaire : une étude menée auprès d' adolescents. Revue canadienne de linguistique appliquée/ Canadian Journal of Applied Linguistics, v. 18, n. 2, p. 28-44, 2015b.

CHARLOT, B. Da relação com o saber. Elementos para uma teoria. Trad.: Bruno Magne. Porto Alegre: Artmed Editora, 2000.

CHARLOT, B. Da relação com o saber às práticas educativas. S . Paulo: Cortez Editora, 2013.

CORTESÃO, M. M. C. R. O ensino de Poesia com Quadro Interativo. Um estudo no 1. ${ }^{\circ}$ Ciclo do Ensino Básico. Dissertação de Mestrado. [s.l.] Universidade de Aveiro, 2012.

CUTLER, L.; GRAHAM, S. Primary Grade Writing Instruction: A National Survey. Journal of Educational Psychology, v. 100, n. 4, p. 907-919, 2008.

DABÈNE, M. L'adulte et l'écriture. Contribution à une didactique de l'écrit en langue maternelle. Bruxelles: De Boeck, 1987.

DABÈNE, M. Des écrits (extra)ordinaires. Eléments pour une analyse de l'activité scripturale. Lidil (Revue de Linguistique et de Didactique des Langues). Des écrits (extra)ordinaires, v. n³, p. 9-26, 1990.

FABRE, D. Écritures ordinaires. Centre Georges Pompidou: Centre Georges Pompidou, Bibliothèque publique d'information, 1993.

FABRE, D.; LA SOUDIÈRE, M. DE; VOISENAT, C. Par écrit ethnologie des écritures quotidiennes textes réunis par Martin de La Soudière et Claudie Voisenat. Paris: Editions de la Maison des Sciences de l'Homme, 1997. v. 11 
FERREIRA, J. M. DA C. A Web 2 . 0 e a escrita no $3 .{ }^{\circ}$ Ciclo do Ensino Básico - a utilização do blogue. [s.l.] Universidade de Aveiro, 2014.

GOMES, H. S. M. L. Reescrita colaborativa: da interacção ao reflexo na escrita individual. Dissertação de Mestrado. Aveiro: Universidade de Aveiro, 2006.

KLEIMAN, A. B. Trajetórias de acesso ao mundo da escrita: relevância das práticas não escolares de letramento para o letramento escolar. Perspectiva, v. 28, n. 2, p. 375-400, 2010.

LAHIRE, B. Sucesso escolar nos meios populares. As razões do improvável (Trad. Ramon Américo Vasques, Sonia Goldfeder). São Paulo: Átila, 2004.

MACARTHUR, C. A. Technology and Struggling Writers: A Review of Research. British Journal of Educational Psychology, Monograph Series II, Number 6 - Teaching and Learning Writing, v. 1, n. 1, p. 159-175, 2009.

NIZA, I.; SEGURA, J.; MOTA, I. Guião de implementação do programa de Português do Ensino Básico - Escrita. Lisboa: Ministério da Educação Direção-Geral de Inovação e de Desenvolvimento Curricular, 2011.

OLIVEIRA, R. M. Escritas de vida, histórias da escola. Na Roda Gigante. Porto: Cordão de Leitura, 2011.

OLSON, D. R. Littératie, scolarisation et cognition. Quelques implications de l'anthropologie de Jack Goody. Pratiques. La Littératie autour de Jack Goody, v. 131-132, p. 83-94, 2006.

PENLOUP, M.-C. L'écriture extrascolaire des collégiens: des constats aux perspectives didactiques. Paris: ESF, 1999.

PENLOUP, M.-C. Les connaissances ignorées: approche pluridisciplinaire de ce que savent les élèves. ParisINRP, , 2008.

PEREIRA, L. Á. Escrever com as crianças - como fazer bons leitores e escritores: para crianças dos 0 aos 12 anos. Porto: Porto Editora, 2008.

PEREIRA, L. Á. Sumário de Lição: A Produção de Textos na Escola - um Percurso para uma Didática (da Literacia) da Escrita. [s.l: s.n.].

PEREIRA, L. Á.; BARBEIRO, L. F. A revisão textual acompanhada como estratégia de ensino da produção escrita. In: LUNA, M. J. DE M.; SPINILLO, A. G.; RODRIGUES, S. G. (ed.). Leitura e produção de texto. Recife: Editora Universitária da UFPE, p. 51-80. 2010.

PEREIRA, L. A.; CARDOSO, I. Ensinar a escrever com os Novos Programas de Português: 2. ${ }^{\circ}$ Ciclo do Ensino Básico. Porto: ASA, 2011.

PEREIRA, L. Á.; CARDOSO, I. Os textos de reflexão (livre) em contexto de formação de professores de escrita: Que género? Que mundos? Que desafios? In: ANDRADE, A. I.; PINHO, A. S. (ed.). Línguas e educação: práticas e percursos de trabalho colaborativo. Perspectivas a partir de um projecto. Aveiro: Universidade de Aveiro, p. 133-156. 2010. 
PEREIRA, L. Á.; CARDOSO, I. Atividades para o ensino da língua - Produção escrita - 1. ${ }^{\circ}$ e 2. ${ }^{\circ}$ Ciclos do Ensino Básico: Protextos, Cadernos PNEP 3. AveiroUniversidade de Aveiro, 2013a.

PEREIRA, L. Á.; CARDOSO, I. A Sequência de ensino como dispositivo didático para a aprendizagem da escrita num contexto de formação de professores. In: PEREIRA, L. Á.; CARDOSO, I. (ed.). . Reflexão sobre a escrita. $\mathbf{O}$ ensino de diferentes géneros de textos. Aveiro: UA Editora, p. 33-65. 2013b.

PEREIRA, L. Á.; CARDOSO, I. Jovens, alunos e relação com a escrita. In: MATOS, M. (ed.). . JOVALES: Jovens, alunos, ensino secundário. Porto: CIIE/Livpsic, 2013c.

PEREIRA, L. Á.; GRAÇA, L. Actividades para o ensino da língua. Cadernos PNEP. Aveiro: Universidade de Aveiro, 2009.

ROSÁRIO, E. M. C. DO. Aprendizagem da escrita através da web 2.0 - Um estudo com alunos do $3^{\circ}$ ciclo do Ensino Básico. Dissertação de Mestrado em Multimédia em Educação. Aveiro: Universidade de Aveiro, 2010.

SCHNEUWLY, B. et al. Géneros orais e escritos na escola. CampinasEditora Mercado de Letras, , 2004.

SIMÕES, A. et al. Colaborar para escrever. In: SILVA, L. M. DA; CLEMENTE, M. (ed.). Línguas e Educação: materiais das oficinas de formação. Aveiro: LALE/CIDTFF Universidade de Aveiro, 2010.

TAVARES, C. F.; BARBEIRO, L. F. As Implicações das TIC no Ensino da Língua. Lisboa: Ministério da Educação, Direcção-Geral de Inovação e de Desenvolvimento Curricular - Programa Nacional de Ensino do Português, 2011.

VEIGA, M. A. DE O. P. A. DA. Escrever para aprender: estratégias, textos e práticas. Tese de Doutoramento. [s.l.] Universidade de Aveiro, 2014.

\section{NOTAS}

${ }^{1}$ Este trabalho é financiado por Fundos Nacionais através da FCT - Fundação para a Ciência e a Tecnologia, I.P., no âmbito do projeto UID/CED/00194/2013.

${ }^{2}$ ProTextos: Ensino e Aprendizagem da Escrita de Textos - http://protextos.web.ua.pt/.

${ }^{3} \mathrm{O}$ ensino secundário passou também a ser escolaridade obrigatória, em 2012, isto é, um total de 12 anos ou até o aluno completar 18 anos.

${ }^{4}$ Instituto de Avaliação Educativa, I. P., "Documentos" - http://iave.pt/np4/home.

${ }^{5}$ Desde 2015, um novo programa entrou em vigor.

${ }^{6}$ Desenvolvidos no âmbito do Plano Nacional de Leitura, a pedido do Gabinete de Estatística e Planeamento da Educação do Ministério da Educação, consultáveis em http:/ / www.planonacionaldeleitura.gov.pt/PNLEstudos/.

${ }^{7}$ Não se consideraram, portanto, as regiões autónomas dos Açores e da Madeira. 
${ }^{8}$ Um agrupamento de escolas é uma unidade organizacional do sistema educativo português, dotada de órgãos próprios de gestão, constituída por estabelecimentos de educação préescolar e de um ou mais níveis e ciclos de ensino, com um projeto pedagógico comum.

${ }^{9}$ Baseamo-nos na classificação das freguesias segundo a Tipologia de áreas urbanas de 2014, Instituto Nacional de Estatística (INE).

${ }^{10}$ Os autores poderão partilhar o questionário na íntegra quando contatados para o efeito.

${ }^{11}$ Algumas conclusões da análise desta questão foram apresentadas no Simpósio Internacional de Ensino de Lingua Portuguesa | Fórum Ibero-Americano de Literacias, na Universidade do Minho, Braga, Portugal, em 2016.

${ }^{12}$ Nove alunos não indicaram o ano de escolaridade.

${ }^{13}$ Segundo a Classificação Nacional de Profissões pelo Instituto do Emprego e Formação Profissional (IEFP).

${ }^{14}$ Essa análise longitudinal já começou a ser feita e parcialmente apresentada no encontro SIG Writing.

${ }^{15}$ Como já dissemos, a verbalização atém-se a uma terminologia corrente para os alunos, independentemente de os itens se identificarem com o que entendemos por géneros de texto, escolares e sociais, ou tipologias textuais.

${ }^{16}$ Todas as perguntas do questionário deram esta possibilidade aos respondentes. No entanto, não as trataremos presentemente.

${ }^{17}$ Talvez estes últimos acusem uma relativa falta de disponibilidade (que pode ser de vária ordem - temporal, mental, emocional...) para escrever por sua livre iniciativa, como já foi confessado por alguns jovens que se queixavam de estar muito ocupados com a escola e outras atividades extracurriculares (CARDOSO, 2009).

${ }^{18}$ Uma análise completa e mais detalhada do questionário em apreço está em curso no âmbito do trabalho de doutoramento de uma das autoras, intitulado "Escrita e TIC: práticas escolares e extraescolares no Ensino Básico", embora com enfoque na utilização e problematização do uso das TIC. Além disso, os resultados deste estudo têm já vindo a ser divulgados, como temos referido.

Submetido: 01/06/2017

Aprovado: 07/08/2018

Contato:

Inês Cardoso

$<$ icardoso@yorku.ca>

<inescardoso@ua.pt>

York University

Faculty of Liberal Arts \& Professional Studies

Department of Languages, Literatures and Linguistics

S510 Ross Building

4700 Keele St., Toronto

Ontario, CANADA M3J 1P3 